\title{
ANALISIS FAKTOR - FAKTOR KEUANGAN DAN ASPEK TEKNOLOGI TERHADAP MARKET SHARE PERBANKAN DI INDONESIA PERIODE 2013-2017
}

\author{
Analysis Of Financial Factors And Technology Factors Of Banking Market Share In Indonesia \\ 2013-2017
}

\author{
Selvi Adelia ${ }^{1}$, Sri Andriani ${ }^{1}$, Nova Adhitya Ananda ${ }^{1}$ \\ Departemen Manajemen, Fakultas Ekonomi dan Bisnis, Universitas Teknologi Sumbawa \\ *) E-mail: selvi.adelia96@gmail.com
}

\begin{abstract}
This study aims to analyze the effect of ROA, BOPO, NPL, and E-banking of the banking market share in Indonesia in 2013-2017. The analytical method used is quantitative causality methode. The data analysis technique used in this study is multiple linear regression analysis. The data used is secondary data in the form of bank financial ratios in 2013-2017. Data collection was taken by means of documentation sourced from bank publication reports. Sampling was done by purposive sampling and obtained a sampel of 21 banks in 2013-2017. The results showed that ROA had no effect and was not significant on market share, BOPO had a negative and significant effect on market share, NPL had a positive and significant effect on market share, and E-banking had a positive and significant effect on market share.
\end{abstract}

Keywords: ROA, BOPO, NPL, E-banking, market share.

\begin{abstract}
ABSTRAK
Penelitian ini bertujuan untuk menganalisis pengaruh ROA, BOPO, NPL dan E-banking terhadap market share perbankan di Indonesia periode 2013-2017. Metode analisis yang digunakan yaitu metode kuantitatif kausalitas. Teknik analisis data yang digunakan dalam penelitian ini yaitu analisis regresi linier berganda. Data yang digunakan yaitu data sekunder berupa rasio keuangan bank periode 2013-2017. Pengumpulan data diambil dengan cara dokumentasi yang bersumber dari laporan publikasi bank. Pengambilan sampel dilakukan secara purposive sampling dan diperoleh sampel sebanyak 21 bank pada periode 2013-2017. Hasil penelitian menunjukkan bahwa ROA tidak berpengaruh dan tidak signifikan terhadap market share, BOPO berpengaruh negatif dan signifikan terhadap market share, NPL berpengaruh positif dan signifikan terhadap market share, serta E-banking berpengaruh positif dan signifikan terhadap market share.
\end{abstract}

Kata Kunci: ROA, BOPO, NPL, E-banking, market share.

\section{Pendahuluan}

Bank memiliki peranan penting dalam setiap aspek. Maka dari itu, bank hendaknya mampu menjaga kepercayaan masyarakat guna memperluas market share dan dapat meningkatkan profitabilitas perusahaan (Rusdiana, 2012). Market share diukur menggunakan kinerja keuangan bank, semakin besar market share perbankan di Indonesia semakin besar pula peran dan fungsinya bagi perekonomian nasional (Saputra, 2014). Untuk mengukur tingkat market share perbankan, menggunakan faktor - faktor kinerja keuangan diantaranya indikator ROA (Return On Assets), BOPO (Biaya Operasional Pendapatan Operasional) dan NPL (Non Performing Loan).

ROA (Return On Assets) merupakan metode pengukuran yang paling objektif yang didasarkan pada akuntansi yang tersedia dan besarnya ROA dapat mencerminkan hasil dari serangkaian kebijakan perusahaan terutama perbankan (Mahardian, 2008). Lalu, menurut Dendawijaya (2009: 119) "rasio BOPO digunakan untuk mengukur tingkat efisiensi dan kemampuan bank dalam melakukan kegiatan operasinya". Dan NPL (Non Performing Loan) merefleksikan besarnya risiko kredit yang dihadapi bank, semakin kecil NPL maka semakin kecil pula risiko kredit yang ditanggung pihak bank
(Mahardian, 2008). Berikut gambar kinerja antara bank konvensional dan bank syariah:

Gambar 1.1 Kinerja Keuangan Bank Konvensional dan Bank Syariah Periode 2013 - 2017

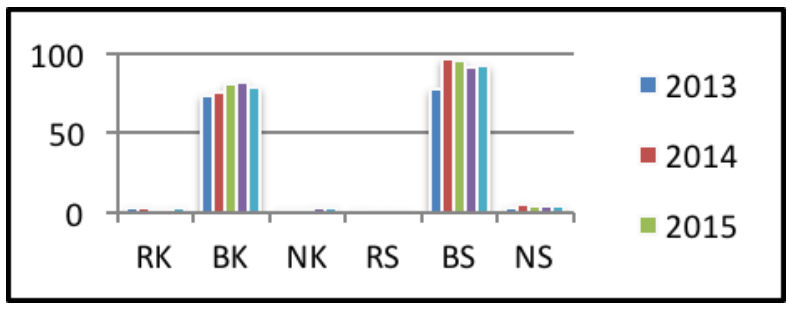

Sumber: Statistik Perbankan Indonesia, data diolah 2017.

Secara umum, tingkat kinerja bank konvensional lebih unggul dibandingkan dengan bank syariah. Akan tetapi market share bank syariah mengalami pertumbuhan secara signifikan. Sepanjang tahun 2016 tren perbankan syariah selalu berada diatas pertumbuhan perbankan konvensional. Market share perbankan syariah menunjukkan peningkatan walaupun pertumbuhan perbankan syariah pada bulan Desember 2016 mengalami penurunan. Hingga Desember 
2016 market share perbankan syariah sebesar 5,3\% meningkat dari bulan Juni 2016 sebesar 4,18\% (Kajian Stabilitas Keuangan, 2017). Dan akhir tahun 2017 tingkat market share bank syariah meningkat menjadi 8,01\% (Otoritas Jasa Keuangan, 2017).

Selain faktor - faktor keuangan yang memengaruhi market share perbankan, salah satu aspek yang penting untuk dinilai yaitu aspek teknologi. Aspek teknologi yang dimaksud yaitu E-banking (Electronic Banking). Tahun 2013, angka pengguna E-banking di Indonesia mencapai 58\%, sedangkan pada tahun 2015, 80\% responden di Indonesia dinyatakan telah menggunakan sarana mobile banking namun masih terdapat $32 \%$ dari jumlah penduduk yang memiliki masalah kepercayaan terhadap penggunaan sarana mobile banking (Karimuddin, 2015). Lalu pada tahun 2017, Otoritas Jasa Keuangan (OJK) mengungkapkan pengguna E-banking cukup meyakinkan, dinyatakan bahwa jumlah pengguna $E$ banking meningkat $270 \%$. Sementara itu, frekuensi transaksi pengguna E-banking meningkat $169 \%$ dari 150,8 juta transaksi tahun 2012 menjadi 405,4 juta transaksi pada 2016 (Fuad, 2017).

\section{Rumusan Masalah}

Berdasarkan uraian latar belakang, dapat dirumuskan masalah sebagai berikut:

1. Bagaimana pengaruh ROA (Return on Assets) terhadap market share perbankan di Indonesia?

2. Bagaimana pengaruh BOPO (Biaya Operasional Pendapatan Operasional) terhadap market share perbankan di Indonesia?

3. Bagaimana pengaruh NPL (Non Performing Loan) terhadap market share perbankan di Indonesia?

4. Bagaimana pengaruh E-banking terhadap market share perbankan di Indonesia?

\section{Hipotesis}

Berdasarkan latar belakang, rumusan masalah, tujuan penelitian dan kerangka konseptual dari penelitian ini maka dapat diajukan hipotesis penelitian sebagai berikut:

1. H1: Return On Assets berpengaruh terhadap market share.

2. H2: Biaya Operasional Pendapatan Operasional berpengaruh terhadap market share.

3. H3: Non Performing Loan berpengaruh terhadap market share.

4. H4: Electronic banking berpengaruh terhadap market share.

\section{METODE PENELITIAN}

\section{Rancangan Penelitian}

Jenis penelitian yang digunakan dalam penelitian ini adalah kuantitatif kausalitas. Dalam penelitian ini yang menjadi variabel independennya adalah ROA, BOPO, NPL dan Electronic banking. Dan variabel dependennya adalah market share perbankan.

\section{Populasi dan Sampel}

Populasi yang digunakan dalam penelitian ini adalah 81 perbankan umum Indonesia yang terdaftar dalam BEI periode 2013 - 2017. Bank umum dalam penelitian ini yaitu bank pemerintah dan bank swasta. Metode penentuan sampel yang digunakan dalam penelitian ini adalah metode purposive sampling.

Sampel dalam penelitian ini dipilih dengan menggunakan purposive sampling dengan kriteria:

1. Bank yang diteliti terdaftar dalam Bursa Efek Indonesia (BEI) dalam periode 2013-2017.

2. Menerbitkan laporan keuangan secara lengkap dari periode 2013-2017.

3. Bank memiliki ROA bernilai positif selama periode 2013-2017.

4. Bank memiliki nilai rasio BOPO dibawah $90 \%$ selama periode 2013-2017.

Dari kriteria tersebut diperoleh 21 sampel perbankan yang terdaftar di BEI dalam periode 2013-2017.

\section{Pengumpulan Data}

Dalam penelitian ini data yang digunakan berupa data sekunder yaitu "data yang diperoleh dengan cara mengumpulkan dokumen atau laporan yang bersumber dari perusahaan atau pihak yang berkaitan dengan penelitian "(Sanusi, 2012: 104). Data sekunder dalam penelitian ini bersumber dari laporan keuangan periode 2013-2017. Sumber dalam mengakses data yang disediakan adalah sumber terpercaya.

\section{Analisis Data}

Uji Normalitas

Uji normalitas bertujuan untuk menguji apakah dalam model regresi variabel terikat dan bebas memiliki distribusi normal (Rusdiana, 2012). Uji ini dilakukan dengan cara melihat penyebaran data pada sumbu diagonal atau gambar dengan menggunakan metode normal probability plot.

\section{Uji Asumsi Klasik}

\section{Uji Autokorelasi}

Autokorelasi adalah "hubungan antara nilai suatu variabel dengan nilai variabel yang sama tetap terjadi pada periode sebelumnya "(Sanusi, 2012: 134). Masalah autokorelasi dapat dideteksi melalui uji Durbin Watson ( $d$ atau DW).

\section{Uji Heteroskedastisitas}

Uji heteroskedastisitas digunakan "untuk melihat apakah residual dari model yang terbentuk memiliki varians yang konstan atau tidak" (Sanusi, 2012: 141). Gejala heteroskedastisitas dapat dideteksi menggunakan uji Rank Spearman.

\section{Uji Multikolinearitas}

"Uji multikolinearitas bertujuan untuk menguji apakah model regresi ditemukan adanya korelasi antar variabel bebas (independen)" (Sanusi, 2012: 136). Pendeteksian terhadap multikolinieritas dapat dilakukan dengan melihat nilai Variance Inflating Factor (VIF) dari hasil analisis regresi.

\section{Regresi Linier Berganda}

Metode yang dipakai dalam menganalisis variabel - variabel dalam penelitian yaitu menggunakan regresi linier berganda untuk mengetahui arah, pengaruh, dan kekuatan hubungan dari variabel independen terhadap variabel dependen. Adapun 
model dasar dari regresi linier berganda dari penelitian ini dapat dirumuskan sebagai berikut:

$$
Y=a+b_{1} X_{1}+b_{2} X_{2}+b_{3} X_{3}+b_{4} X_{4}+e
$$

Keterangan:

Y: Variabel Dependen Market share

$\mathrm{X}_{1}$ : Variabel Independen ROA

$\mathrm{X}_{2}$ : Variabel Independen BOPO

$\mathrm{X}_{3}$ : Variabel Independen NPL

$\mathrm{X}_{4}$ : Variabel Electronic banking

a: Konstanta

b $(1,2,3,4)$ : Koefisien Regresi

\section{e: Error Term}

\section{Pembahasan Hasil Penelitian}

\section{Gambaran Umum Objek Penelitian}

Objek dalam penelitian ini adalah bank umum yang beroperasi di Indonesia periode 2013-2017. Bank umum yang digunakan dalam penelitian ini yaitu bank pemerintah dan bank swasta dengan total 81 bank. Setelah dilakukan pemilihan sampel menggunakan metode purposive sampling, maka sampel yang layak digunakan atau memenuhi kriteria dalam penelitian ini yaitu 21 bank yang terdaftar di BEI peiode 2013-2017. Data diambil dari laporan tahunan bank bank tersebut.

Tabel 4.1 Uji Statistik Deskriptif

\begin{tabular}{|l|r|r|r|r|}
\multicolumn{7}{c|}{ Descriptive Statistics } \\
\hline & \multicolumn{1}{|c|}{ N } & Minimum & Maximum & \multicolumn{1}{c|}{ Mean } \\
\hline Market Share & 105 & .0200 & 19.8000 & 3.128476 \\
ROA & 105 & .1500 & 5.4200 & 2.112476 \\
BOPO & 105 & 54.1300 & 89.9200 & 80.192857 \\
NPL & 105 & .0800 & 4.9000 & 1.847810 \\
E-banking & 105 & 1.0800 & 28.0000 & 6.512857 \\
Valid N (listwise) & 105 & & & \\
\hline
\end{tabular}

Sumber: Output SPSS.

\section{Hasil Uji Asumsi Klasik}

Uji Autokorelasi

Tabel 4.2 Uji Autokolerasi (Data Asli Periode 2013-2017) Model Summary

\begin{tabular}{|l|l|r|r|r|r|}
\hline Model & $R$ & R Square & $\begin{array}{c}\text { Adjusted R } \\
\text { Square }\end{array}$ & $\begin{array}{c}\text { Std. Error of } \\
\text { the Estimate }\end{array}$ & $\begin{array}{c}\text { Durbin- } \\
\text { Watson }\end{array}$ \\
\hline 1 & $.776^{\mathrm{d}}$ & .602 & .585 & .54048 & .593 \\
\hline
\end{tabular}

Sumber: Output SPSS

Berdasarkan tabel statistik d (Durbin-Watson) nilai kritis $d_{L}$ dan $\mathrm{d}_{\mathrm{U}}$ adalah $\mathrm{d}_{\mathrm{L}}=1,5993$ dan $\mathrm{d}_{\mathrm{U}}=1,7603$. Apabila dimasukkan ke dalam rumus kriteria maka 0,593 < 1,5993 yang mengindikasikan bahwa terjadi autokolerasi positif.

Tabel 4.3 Uji Autokolerasi (Data Setelah Transformasi Log)

Model Summary
\begin{tabular}{|c|c|r|r|r|c|}
\hline Model & R & R Squareb & $\begin{array}{c}\text { Adjusted R } \\
\text { Square }\end{array}$ & $\begin{array}{c}\text { Std. Error of } \\
\text { the Estimate }\end{array}$ & $\begin{array}{c}\text { Durbin- } \\
\text { Watson }\end{array}$ \\
\hline 1 & $.870^{\mathrm{a}}$ & .757 & .747 & .33047 & 1.786 \\
\hline
\end{tabular}

Sumber: Output SPSS

Dari hasil pengujian kedua setelah data ditransformasikan, diperoleh hasil bahwa apabila nilai DW dimasukkan dalam rumus kriteria maka 1,7603 < 1,786 <2,2397. Keputusannya adalah tidak terjadi autokolerasi.

Uji Heteroskedastisitas

Tabel 4.4 Uji Heteroskedastisitas

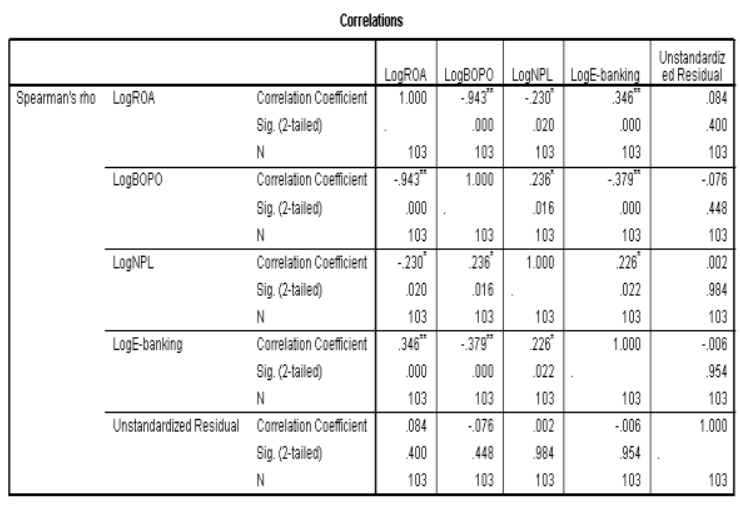

Sumber: Output SPSS

Berdasarkan tabel di atas, dapat diketahui bahwa pada tabel bahwa nilai siginifikan variabel memiliki nilai signifikan lebih dari 0,05,sehingga dapat disimpulkan tidak terjadi gejala heteroskedastisitas.

Uji Multikolinearitas

Tabel 4.5 Uji Multikolinearitas

\begin{tabular}{ccc}
\hline Model & \multicolumn{2}{c}{ Collinerity Statistics } \\
& Tolerance & VIF \\
\hline LogROA & 0,324 & 3,090 \\
LogBOPO & 0,309 & 3,236 \\
LogNPL & 0,836 & 1,196 \\
LogE- & 0,759 & 1,318 \\
banking & \\
\hline \multicolumn{2}{c}{ Sumber: Output SPSS }
\end{tabular}

Dari hasil yang didapatkan, korelasi di atas menunjukkan bahwa hubungan antar variabel independen tidak memiliki gejala multikolinearitas karena semua variabel independen memiliki nilai VIF $<10$ dan nilai tolerance $>0,10$. Maka model regresi layak untuk dipakai.

\section{Persamaan Regresi Barganda}

Pembentukan persamaan regresi berganda dengan menggunakan output SPSS dapat dilakukan dengan 
menginterprestasikan angka - angka yang termuat ke dalam Unstandardized Coefficients B dalam tabel di bawah ini:

\section{Tabel 4.6 Uji Regresi Linier Berganda}

\begin{tabular}{|c|c|c|c|c|c|c|}
\hline & & & & \multicolumn{3}{|c|}{ Coefficients $^{a}$} \\
\hline \multirow[b]{2}{*}{ Model } & & \multicolumn{2}{|c|}{ Unstandardized Coefficients } & \multirow{2}{*}{$\begin{array}{c}\begin{array}{c}\text { Standardized } \\
\text { coefficients }\end{array} \\
\text { Beta } \\
\end{array}$} & \multirow[b]{2}{*}{$t$} & \multirow[b]{2}{*}{ Siq. } \\
\hline & & & Std. Error & & & \\
\hline \multirow[t]{5}{*}{1} & $\overline{\text { (Constant) }}$ & .072 & .852 & & .084 & .933 \\
\hline & LogROA & .026 & .384 & .008 & .069 & .945 \\
\hline & LogBOPO & -4.901 & 1.764 & -.319 & -2.779 & .007 \\
\hline & LogNPL & .393 & .143 & .192 & 2.748 & .007 \\
\hline & LogE-banking & 1.342 & 178 & .551 & 7.531 & .000 \\
\hline
\end{tabular}

Sumber: Output SPSS

Dengan memperhatikan angka yang berada pada kolom Unstandardized Coefficients B dapat disusun dalam persamaan regresi linier berganda sebagai berikut:

$\log Y=0,072+0,026 \log X_{1}-4,901 \log X_{2}+0,393 \log X_{3}+$ $1,324 \log X_{4}+e$

\section{Pengujian Hipotesis}

\section{Variabel ROA}

Estimasi regresi variabel ROA diperoleh nilai thitung sebesar 0,069 lebih kecil dari nilai tabel yaitu 1,984 dengan tingkat signifikansi $0,945>0,05$. Hal ini berarti bahwa $\mathrm{H}_{0}$ diterima atau hipotesis yang menyatakan ROA secara parsial berpengaruh terhadap market share ditolak. Market share dihitung melalui total aset yang dimiliki bank. Total aset dalam bank $80 \%$ berasal dari dana pihak ketiga atau DPK. Dalam hal ini dana pihak ketiga yang dimaksud yaitu masyarakat, dalam arti masyarakat sebagai individu, perusahaan, pemerintah, rumah tangga, koperasi, yayasan dan lain - lain. Masyarakat yang berperan sebagai pemberi dana pihak ketiga kepada perbankan, tidak memprioritaskan ROA sebagai faktor yang menentukan untuk menabungkan uangnya di bank tersebut, melainkan karena terdapat faktor lain yang menjadi daya tarik masyarakat seperti besarnya tingkat suku bunga yang ditawarkan.

\section{Variabel BOPO}

Hasil estimasi regresi variabel BOPO diperoleh nilai thitung > $t_{\text {tabel }}$ yaitu $-2,779>-1,984$ dan nilai signifikan yaitu 0,007. Yang berarti bahwa $\mathrm{H}_{0}$ ditolak atau hipotesis yang menyatakan BOPO secara parsial berpengaruh terhadap market share diterima serta nilai signifikan $0,007<0,05$ berarti pengaruhnya signifikan. Sedangkan berdasarkan persamaan regresi terlihat bahwa koefisien untuk variabel BOPO bernilai negatif. Hal ini berarti semakin tinggi nilai BOPO mengakibatkan semakin rendah tingkat market share perbankan.

Dalam hal ini, masyarakat menilai biaya yang dikeluarkan bank penting untuk penentuan tingkat pendapatan yang tidak hanya berdampak terhadap laba namun juga berdampak terhadap kelangsungan hidup serta kegiatan operasional bank. Sebagai pihak pemberi dana, masyarakat tentunya ingin mengetahui tingkat kemampuan bank dalam mengendalikan biaya yang dikeluarkan untuk meningkatkan tingkat kepercayaan masyarakat menyimpan dana yang dimiliki di bank tersebut.

\section{Variabel NPL}

Hasil estimasi regresi variabel NPL diperoleh nilai thitung $>$ $t_{\text {tabel }}$ yaitu $2,748>1,984$ dan nilai signifikan yaitu 0,007 . Berarti bahwa $\mathrm{H}_{0}$ ditolak atau hipotesis yang menyatakan bahwa NPL secara parsial berpengaruh terhadap market share diterima. Serta nilai signifikan $0,007<0,05$ berarti bahwa pengaruhnya signifikan. Sedangkan berdasarkan persamaan regresi terlihat bahwa koefisien variabel NPL bernilai positif. Hal ini berarti semakin tinggi nilai NPL maka tingkat market share akan meningkat. Hal ini terjadi karena rata -rata nilai NPL bank yang beroperasi pada periode 20132017 sebesar 1,84\% yang masih berada dalam batas maksimum NPL yang telah disyaratkan oleh Bank Indonesia yaitu $5 \%$.

\section{Variabel E-banking}

Hasil estimasi regresi variabel E-banking diperoleh nilai Variabel E-banking memiliki nilai thitung $>t_{\text {tabel }}$ sebesar 7,531 $>1,984$ dan nilai signifikan sebesar 0,000. Berarti bahwa $\mathrm{H}_{0}$ ditolak atau hipotesis yang menyatakan bahwa E-banking berpengaruh terhadap market share diterima. Dan nilai signifikan yaitu $0,000<0,05$ berarti bahwa terdapat pengaruh signifikan. Sedangkan berdasarkan persamaan regresi terlihat bahwa koefisien variabel $E$-banking bernilai positif. Hal ini memiliki arti bahwa semakin tinggi nila E-banking maka semakin tinggi tingkat market share.

Inovasi terbaru terkait dengan pengembangan layanan teknologi perbankan perlu ditingkatkan dan diperbarui. Dalam hal ini, pihak yang menggunakan fitur layanan teknologi yang disediakan merasa bahwa dengan adanya fitur - fitur layanan terbaru maka akan mempermudah transaksi antara sesama pengguna layanan tersebut. Sehingga dapat meminimalisir biaya dan meningkatkan pendapatan serta market share perbankan.

\section{Penutup}

\section{Kesimpulan}

Berdasarkan pada hasil penelitian dan pembahasan yang telah diuraikan sebelumnya maka disimpulkan sebagai berikut:

1. Berdasarkan hasil perhitungan yang telah dilakukan secara parsial variabel ROA tidak berpengaruh terhadap market share perbankan yang terdaftar di BEI periode 2013-2017, karena masyarakat tidak memperioritaskan ROA sebagai faktor yang mendorong masyarakat untuk menabungkan uangnya di bank.

2. Variabel BOPO secara parsial berpengaruh negatif terhadap market share perbankan yang terdaftar di BEI periode 2013-2017, karena pengendalian biaya penting bagi kelangsungan operasional perbankan.

3. Variabel NPL secara parsial berpengaruh positif terhadap market share perbankan yang terdaftar di BEI periode 2013-2017, karena tingkat NPL yang dimiliki bank berada dibawah 5\% sebagai batas maksimum NPL yang diberikan oleh Bank Indonesia.

4. Variabel E-banking secara parsial berpengaruh positif terhadap market share perbankan yang terdaftar di BEI periode 2013-2017, karena fitur layanan E-banking yang diberikan memberikan kemudahan dan efisiensi waktu dalam bertransaksi. 


\section{Daftar Pustaka}

Bank Indonesia. 2017. Kajian Stabilitas Keuangan.

Bank Indonesia. 2018. Kajian Stabilitas Keuangan.

Collins, James. C dan Jerry I. P. 2001. Built to Last: Tradisi Sukses Perusahaan Visioner (Terj. Hifni Alifahmi), Nurcahyo Mahanani (Ed). Jakarta: Erlangga.

Dendawijaya, Lukman. 2009. Manajemen Perbankan. (Edisi 2). Bogor: Ghalia Indonesia.

Fuad, Hafid. 2017. "Pengguna e-Banking Meningkat Tajam", (Online) (http://sindonews.com, diakses 9 Mei 2018).

Hapsari, Nabela. 2015. "Pengaruh Internet Banking, NPF, DPK dan BOPO Terhadap Laba".

http://www.bi.go.id, diakses 25 Mei 2018.

http://www.idx.co.id, diakses 28 Juni 2018.

Karimuddin, Amir. 2015. "MEF: Penggunaan Mobile Banking Capai $80 \%$ di Indonesia, Isu Kepercayaan Menjadi Masalah Terbesar", (Online) (http://dailysocial.id, , diakses 9 Mei 2018).

Mahardian, Pandu. 2008. "Analisis Pengaruh Rasio CAR, BOPO, NPL, NIM dan LDR Terhadap Kinerja Keuangan Perbankan (Studi Kasus Perusahaan Perbankan yang Tercatat di BEJ Periode Juni 2002 - Juni 2007)". Tesis Program Magister Manajemen Universitas Diponegoro Semarang.

Muchlish, Abraham dan Dwi Umardani. 2016. "Analisis Perbandingan Kinerja Keuangan Bank Syariah dan Bank Konvensional di Indonesia" dalam Jurnal Manajemen dan Pemasaran Jasa, Vol. 9, No. 1, hlm. 129- 155.

Otoritas Jasa Keuangan. 2017. "Siaran Pers: Market share Keuangan Syariah Capai 8 Persen", (Online) (http://ojk.go.id, diakses 27 April 2018).

Perkasa, Ponttie. P. 2007. “Analisis Pengaruh Rasio Rasio Keuangan Terhadap Kinerja Bank Umum di Indonesia (Studi Empiris Bank - Bank Umum yang Beroperasi di Indonesia)". Tesis Program
Magister Sains Akuntansi Universitas Diponegoro Semarang.

Rahman, Aulia. 2016. "Analisis Faktor - Faktor yang Mempengaruhi Market share Bank Syariah" dalam Jurnal Analytica Islamica, Vol. 5, No.2, hlm. 291-314.

Rekarti, Endi dan Mafizatun Nurhayati. 2016. “Analisis Structure Conduct Performance (SCP) Jika Terjadi Merger Bank Pembangunan Daerah dan Bank BUMN Persero Berdasarkan Nilai Aset dan Nilai Dana" dalam Jurnal Ilmiah Manajemen dan Bisnis, Vol. 2, No. 1, hlm. 36-50.

Rusdiana, Nana. 2012. "Analisis Pengaruh CAR, LDR, NIM, NPL, BOPO dan DPK Terhadap Kinerja Keungan Perbankan (Studi Kasus pada Bank Umum yang Terdaftar pada Bursa Efek Indonesia Periode 2008-2011)". Skripsi Program Ekonomi Manajemen Universitas Diponegoro Semarang.

Sandy, Muhamad. 2017. “Analisis Pengaruh Faktor Faktor Kinerja dan Aspek Teknologi Terhadap Market share Perbankan Syariah di Indonesia Periode 2011-2016". Tesis Program Magister Perbankan Syariah Universitas Islam Negeri Syarif Hidayatullah Jakarta.

Sanusi, Anwar. 2012. Metodologi Penelitian Bisnis. Jakarta: Salemba Empat.

Saputra, Bambang. 2014. "Faktor - Faktor Keuangan yang Mempengaruhi Market Share Perbankan Syariah di Indonesia" dalam Jurnal Akuntabilitas, Vol. 7, No. 2, hlm. 123-131.

Subramanyam, K. R dan John J. W. 2010. Analisis Laporan Keuangan. (Edisi 10). Jakarta: Salemba Empat.

Syaifuddin, D. T. 2007. Manajemen Perbankan (Pendekatan Praktis). Sulawesi Tenggara: Unhalu Press.

Zen, Nasuha. 2015. "Analisis Structure, Conduct and Performance Industri Perbankan Syariah Indonesia Tahun 2011-2014 (Hipotesis Tradisional, Diferensiasi dan Efisiensi)". 